\title{
PELAKSANAAN METODE PEMBELAJARAN TAHFIZH AL-QUR'AN DI MADRASAH TAHFIDZ AL-QUR'AN AL-IMAM 'ASHIM TIDUNG MARIOLO, MAKASSAR
}

\author{
Implementation of Memorizing Learning Method of Holy Qur 'an \\ at Madrasah Tahfidz Al-Quran Al-Imam 'Ashim Tidung Mariolo, Makassar \\ Muhammad Sadli Mustafa * \\ *Balai Litbang Agama Makassar \\ Jl. A.P. Pettarani No. 72 Makassar \\ Email: $\operatorname{ciccixc}(\mathrm{g}>$,yahoo.com \\ Koreksi naskah I tanggal 2 Juni 2012. Koreksi naskah II tanggal 15 Juli 2012. Finalisasi Naskah 9 Oktober 2012
}

\begin{abstract}
Abstrak
Tenia penelitian ini terkait dengan pembelajaran tahfizh Alquran yang lebih diarahkan pada proses pembelajarannya di Madrasah Tahfidz Alquran al-Imam 'Ashim Tidung Mariolo Makassar. Penelitian dimaksudkan untuk mengungkap secara deskriptifprogram dan metode pembelajaran dalam meningkatkan kualitas dan kuantitas hafalan Alquran para santrinya. Data dikumpulkan melalui observasi, wawancara, dokumentasi dan triangulasi, serta mengacu literatur yang relevan dengan tema yang diangkat. Hasil penelitian menunjukkan bahwa pembelajaran tahfizh Alquran di Madrasah Tahfizh Alquran al-lmam 'Ashim digunakan metode talaqqi wa al-musydfahah yang diterapkan melalui duaprogram pembelajaran yakni program bi al-nazi $r$ dan program bi al-gaib. Pencapaian tersebut telah menghasilkan sejumlah hdfizh Alquran yangpandai dan terampil melafalkan ayat suci Alquran dengan baik dan fasih.
\end{abstract}

KataKunci: Pelaksanaan, Metode Pembelajaran, Tahfizh Alquran, Madrasah Tahfidz al-Qur 'an al-Imam 'Ashim, Makassar

\begin{abstract}
The theme of this research related to learning memorization of the holy Qur 'an which are more focused on the learning process in Madrasah Tahfidz al-Qur 'an al-Imam Asim Tidung Mariolo Makassar. It is intended to reveal descriptively related programs and learning methods in improving the quality and quantity of memorization of the holy Qur'an to students. The data collected through observation, interviews, documentation and triangulation and also referry literature relevant to the theme. Results showed that memorization learning of the holy Qur 'an in Madrasah Tahfidz al-Qur 'an al-Imam Ashim implementing talaqqii wa al-musydfahah method through two learning programs namely bi al-nazhr and bi al-gaib programs. The achievement of this method has produced a number of Qur'anic memorizers clever and skillfully recite the holy verses of the Qur 'an well andfluently.
\end{abstract}

Keyword: Implementation, learning Method, memorization of the holy Qur'an, Madrasah Tahfidz alQur'an al-Imam Ashim, Makassar

\section{PENDAHULUAN}

$\mathrm{D}$ i Sulawesi Selatan khususnya di kota Makassar, lembaga pendidikan yang menyelenggarakan pembelajaran tahfizh Alquran masih sangat kurang, walaupun program pengentasan buta aksara Alquran telah banyak digalakkan, akan tetapi kualitasnya hanya sampai pada taraf membaca dengan lancar dan fasih saja, belum sampai pada taraf menghafal keseluruhan ayat-ayat Alquran. Program pembelajaran tahfizh Alquran sangat penting, karena selain sebagai upaya pemeliharaan keautentikan Alquran, para penghafal Alquran saat ini sangat dibutuhkan baik dalam membantu masyarakat memakmurkan masjid maupun dalam membantu pemerintah menyukseskan program di bidang keagamaan. Oleh karena itu, lembagalembaga yang khusus membina tahfizh Alquran perlu dibangun dan dikembangkan dengan sistem pembelajaran yang bisa menghasilkan alumni berkualitas.

Salah satu lembaga yang melaksanakan program pembelajaran tahfizh Alquran di Makassar adalah Madrasah Tahfidz Alquran al-Imam 'Ashim Tidung Mariolo, sekaligus menempatkannya sebagai fokus 
kajian mengenai pelaksanaan metode pembelajaran yang diterapkan meliputi program pembelajaran terhadap santri yang baru belajar memperbaiki bacaan Alquran dan santri yang sedang dalam tahap menghafal Alquran serta perkembangan Madrasah itu sendiri.

\section{Teori}

Di dalam Alquran dan hadis terdapat konsep dasar metodologi yang baik untuk diterapkan dalam melakukan pembelajaran Alquran, baik dalam upaya pengentasan buta aksara Alquran maupun untuk membina generasi Islam menjadi hdfizh (penghafal) Alquran. Konsep dimaksud dapat dilihat dalam Q.S. al-'Alaq (96): 1-5 dan lebih jelas lagi dalam Q.S. alQiyamah (75): 18 yang artinya "maka apabila kami telah selesai membacakannya maka ikutilah bacaan itu".' Jadi, sebenarnya metode itu sudah diterapkan sejak wahyu pertama diturunkan di mana malaikat Jibril membacakan wahyu lalu Nabi saw. mengikuti bacaan itu. Nabi saw. melakukan hal serupa dalam mengajarkan Alquran kepada para sahabat, sebagaimana dalam catatan sejarah disebutkan bahwa setiap kali Rasul saw. menerima wahyu, beliau kemudian membacakan ditengah-tengah sahabatnya, setelah itu sahabat pun mengikuti dan seakan saling berlomba menghafalnya serta senantiasa membacanya dalam shalat dan mengulang-ulang bacaannya di waktu siang maupun malam. Kegiatan seperti ini dalam Alquran disebut al-Jam 'u al-Qur 'an fi al-Shudur (mengumpulkan Alquran dalam dada atau dengan kata lain menghafal Alquran). ${ }^{2}$ Kegiatan ini terus dilanjutkan oleh para sahabat, ${ }^{3}$ tabi'in, hingga generasi sekarang. ${ }^{4}$

Rasul saw mengembangkan metode tersebut dengan jalan memilih orang-orang tertentu dari para sahabat untuk mengajarkan Alquran. Ini dapat dilihat dalam sebuah hadis yang diriwayatkan 'Abdullah ibn 'Amr ibn al-'Ash, ia berkata: saya mendengar Rasul saw. bersabda: ambillah Alquran dari empat orang: 'Abdullah ibn Mas'ud, Salim, Mu'az, dan Ubay bin Ka'b". Hadis ini menunjukkan bahwa dalam mengajarkan Alquran kepada para sahabatnya, Rasul saw mengangkat beberapa orang diantara sahabatsahabatnya untuk mengajarkan Alquran sesuai dengan bacaan yang mereka ketahui langsung dari Nabi kepada sahabat yang lain. Tidaklah mengherankan dalam silsilah (sanad) bacaan Alquran banyak pula ditemukan sahabat yang meriwayatkan dari sahabat yang menerima langsung dari Nabi seperti 'Abdullah ibn 'Abbas dan Abu Hurairah yang mempelajari Alquran dari sahabat Ubay ibn Ka'ab dan Zaid ibn Tsabit. Begitu juga Anas ibn Malik yang belajar dari Zaid ibn Tsabit dan sebagainya.

Tatap muka antara guru dan murid serta membaca langsung Alquran di hadapan seorang guru merupakan unsur penting dalam sistem pembelajaran tahfizh Alquran. Unsur-unsur tersebut diistilahkan dengan talaqqi wa al-musydfahah. Talaqqi berarti pertemuan atau tatap muka, al-musydfahah berarti membaca langsung. Talaqqi wa al-musydfahah adalah suatu metode yang digunakan dalam pembelajaran Alquran dengan tatap muka dan membaca langsung di hadapan guru, ' sedang untuk menjaga kekuatan hafalan Alquran maka harus dilakukan pengulangan atau takrir (pengulangan). Untuk mengakomodir jumlah murid yang semakin banyak maka perlu diangkat seorang yang ahli untuk membantu kelancaran pembelajaran. Metodemetode tersebut digunakan dalam menelaah temuan penelitian ini.

\section{Metode Penelitian}

Penelitian dilakukan selama empat bulan mulai dari bulan Mei hingga Agustus 2009 dengan menggunakan pendekatan kualitatif. Populasi atau "social situa-

Yayasan Penyelenggara Penerjemah/Pentashih Mushaf Alquran Departemen Agama Republik Indonesia, Alquran dan Terjemahnya (Bandung: PT. Syaamil Cipta Media, 2005), h. 577.

Manna' al-Qaththan, Mabdhits ft 'Uliim al-Qur'dn (Cet. Ill; t.tp.: Mansyurat al-'Ashr al-Hadits, t. th.), h. 123. Lihat juga Syauqi Dhif, Kildb al-Sab 'ah li Ibn al-Mujdhid (Cet.IIl; Kairo: Dar al-Ma'arif; t. th.), h. 9

'Muhammad 'All al-Shabuni, Al-Tibydn ft •Ulum al-Qur'an (Cet. I; Beirut: 'Alim al-Kutub, 1405 H./1985 M.), h. 59-60. Lihat juga Sihr al-Sayyid 'Abd al-'Aziz Salim, 'Adwd'u 'aid Mushaf 'Utsmdn ibn 'A/fan wa Rihlalih Syaraqan wa Garaban (Iskandariyah: Mu'assasah Syabab al-Jami'ah, 1411 H./1991 M.), h. 15-16.

‘A1-Imam al-Hafizh Abu al-Khair Muhammad ibn Muhammad al-Damasyqi ibn al-Jazari, Al-Nasyr ft al-Qird'dt al-'Asyr, Juz I (Cet. I; Beirut: Dar al-Kutub al-'Ilmiyyah, 1418 H./1998 M), h. 13-14. Bandingkan dengan Hasanuddin AF., Anatomi Alquran; Perbedaan Qira'at dan Pengaruhnya Terhadap Islinbath Hukum (Cet. I; Jakarta: RajaGrafindo Persada, 1995), h. 300-308.

Abu 'Abdullah Muhammad ibn Ismaa'il ibn Ibrahim ibn al-Mugirah ibn Bardizabah al-Bukhari al-Ju'fl, Shahih Bukhdri, Juz VI (Cet. I; Beirut: Dar al-Kutub al-'Ilmiyyah, 1412 H/1992 M.), h. 419.

'Sya'ban Muhammad Isma'il, Al-Qird'atu Ahkdmuhd wa Mashddruhd diterjemahkan oleh Said Agil Husin al-Munawar, Abdurrahman Umar dan Nashrullah Jamaluddin dengan judul Mengenai Qira'at Alquran (Cet. I; Semarang: Dina Utama, 1993), h. 64-65.

'Lihat Ahmad Fathoniy, Kaidah Qira'at Tujuh, Jilid 1 (Cet. II; Jakarta: Darul Ulum Press, 1996), h. 1-4. 
Hon"\} dalam penelitian ini terdiri atas tiga elemen. Elemen dimaksud adalah pertama, tempat (place), yaitu Madrasah Tahfidz Alquran al-Imam 'Ashim Tidung Mariolo Kelurahan Tidung Kecamatan Rappocini Kota Makassar. Kedua, pelaku (actors), yaitu pimpinan, guru dan tenaga kependidikan di Madrasah tersebut. Ketiga, aktivitas (activity), yaitu pembelajaran tahflzh Alquran. Penentuan narasumber dilakukan secara purposive.

Pengumpulan data dilakukan dengan cara observasi, wawancara, dokumentasi dan triangulasi. Observasi partisipatif moderat dilakukan untuk memperoleh data yang lebih lengkap dengan cara peneliti mengikuti secara seksama proses pembelajaran tahflzh Alquran dan terlibat langsung dalam sebagian proses pembelajaran itu. Jenis wawancara yang digunakan adalah wawancara tidak terstruktur dengan menggunakan pedoman wawancara dan fleldnote. Wawancara dilakukan terhadap Pimpinan Yayasan al-Imam Ashim, guru dan beberapa peserta didik dan tokoh masyarakat setempat. Untuk melengkapi hasil observasi dan wawancara, dilakukan studi dokumen terkait proses pembelajaran tahflzh Alquran dan lembaga yang melaksanakan seperti profil lembaga, catatan pribadi, tata tertib, jumlah guru dan jumlah peserta didik dan lain-lain. Selain itu, penulis juga menggunakan peralatan mekanik berupa kamera untuk merekam bentuk-bentuk atau peristiwa-peristiwa terkait dengan proses pembelajaran tahflzh Alquran. Adapun triangulasi dilakukan untuk memahami lebih dalam apa yang ditemukan. ${ }^{10}$

\section{PEMBAHASAN}

\section{Sejarah Singkat Berdirinya Madrasah Tahfidz Alquran al-Imam 'Ashim Tidung Mariolo}

Sejarah Madrasah ini bermula ketika Sy am Amir kembali ke Makassar pada tahun 1996, setelah lebih dari enam tahun menempuh pendidikan di Pondok Pesantren Madrasatul Quran Tebu Ireng Jombang. Ia merupakan murid Imam Shafwan, salah seorang murid KH. Yusuf Masyhar yang merupakan pengasuh Madrasatul Quran Tebu Ireng. KH. Yusuf Masyhar adalah salah satu murid KH. Muhammad Dahlan Khalil, satu dari lima orang yang menjadi sumber sanad (periwayatan bacaan Alquran bersambung sampai kepada Nabi saw) di wilayah Jawa dan Madura.

Syam Amir kemudian tergerak dan mulai mengamalkan ilmu yang telah diperoleh. Saat itu hanya adik-adik, beberapa orang teman, tetangga dan kerabat dekat yang belajar bacaan Alquran secara privat. Kegiatan itu bertempat di rumah dan terus berlangsung hingga ia mendirikan TPA(Taman Pendidikan Alquran) tahun 1998 dan berhasil mewisuda 16 santri. Sejak didirikan sampai tahun 2009 telah mewisuda santri dan santriwati sebanyak 405 orang. Santri dan santriwati TPA terdiri dari anak-anak dan remaja yang baru belajar membaca Alquran. Metode yang digunakan di TPA adalah metode Iqra'. Aktivitas pembelajaran di TPA ini dan metode yang digunakan masih tetap berjalan sampai sekarang.

Pada tanggal 23 Desember 1999 bertepatan dengan tanggal 17 Ramadhan 1420 H. Syam Amir mendirikan lembaga yang khusus mengajarkan tahflzh (hafalan) Alquran. Lembaga itu dinamakan Madrasatul Quran al-Imam 'Ashim. Ada tiga alasan yang menginspirasi berdirinya Madrasah ini, yakni:

a. Keinginan melanjutkan tradisi pemeliharaan Alquran.

b. Berkurangnya minat masyarakat dalam menghafal Alquran.

c. Semakin langkanya ulama atau guru penghafal Alquran karena banyak yang sudah wafat.

Program pembelajaran tahflzh Alquran, diperuntukkan bagi mereka yang berminat menghafal Alquran. Adapun qird 'ah yang diajarkan bagi santri tahflzh Alquran adalah qird'ah 'Ashim riwayat Hafsh. Qird'ah ini kemudian menjadi dasar bagi mereka yang berminat mempelajari qird 'at Alquran lebih mendalam. Qird'ah 'Ashim riwayat Hafsh merupakan qird 'ah yang populer digunakan oleh kaum muslim di seluruh dunia termasuk di Indonesia.'

Pada awal didirikan Madrasah ini hanya menerima murid laki-laki (santri) saja. Madrasah ini baru menerima santriwati pada pertengahan tahun 2005, namun sangat terbatas yaitu hanya satu orang dan tenaga pengajarnya pun hanya Rugaiyah (istri pimpinan

\footnotetext{
${ }^{8}$ Lihat Sugiyono, Metode Penelitian Kuantilatif, Kualitatif dan R\&D (Cet. VI; Bandung: Alfabeta, 2009); h. 215-216.

Ibid.

"Sugiyono, Memahami Penelitian Kualitatif (Cet. Ill; Bandung: Alfabeta, 2007), h. 222-240.

"Taufik Adnan Amal, Rekonstruksi Sejarah Alquran, Edisi I (Cet. I; Yogyakarta: FkBA, 2001), h. 323-324.
} 
Madrasah). Hal ini disebabkan karena keterbatasan sarana dan prasarana. Pada pertengahan tahun 2006, bertambah dua orang santriwati. Namun. pada tahun 2007 satu orang santriwati keluar dengan alasan ingin melanjutkan sekolah. Tahun 2008, tak ada lagi santriwati yang tersisa. Semuanya keluar dengan alasan tidak mampu meneruskan hafalan dan ingin bersekolah saja.

Pada tahun 2002 LPTQ (Lembaga Pengembangan Tilawatil Quran) Pusat membuka cabang baru pada STQ/MTQ Nasional yakni cabang qird'dt sab'ah. para qdri' dan qdri'ah yang ingin memantapkan pengetahuannya tentang qird 'at sab 'ah khususnya bacaan yang dipertandingkan di event MTQ cabang qird'dt sab'ah belajar di pesantren ini. Kegiatan ini terus berjalan hingga sekarang. Pada awal tahun 2009 dibuka pula program qird 'at sab 'ah untuk kalangan hdflzh yang ingin memperdalam qird'dt Alquran khususnya qird 'at sab 'ah.

Pada tahun 2008 Syam Amir membentuk yayasan dengan nama Yayasan al-Imam 'Ashim. Ia juga mengubah nama Madrasatul Quran menjadi Madrasah Tahfidz Alquran dengan maksud agar ciri khasnya sebagai lembaga yang khusus menerapkan sistem pembelajaran tahfizh Alquran tampak dari namanya. Yayasan yang baru dibentuk itu menaungi Madrasah dan TPA yang ada. Pada tahun ini pula dibangun asrama yang sangat sederhana di kampus 11 .11. Tamangngapa Kel. Bangkala Kec. Manggala, Makassar. Asrama tersebut digunakan sebagai tempat sementara bagi santri secara bergilir setiap pekan untuk melakukan takrir (pengulangan) terhadap hafalannya. Di lokasi ini rencananya akan dibangun pula Madrasah Tsanawiyah. Pada saat penelitian ini dilakukan, madrasah dan asrama tersebut sedang dalam tahap pembangunan.

Pada awal tahun 2009 didirikan pula Madrasah Tahfidz Alquran khusus puteri yang berlokasi di asrama sementara di jl. Racing Centre Kompleks Perumahan Dosen Umi Blok H Makassar.

Menurut keterangan pimpinan Madrasah bahwa setiap tahun santri silih berganti yang masuk dan keluar. Tetapi, jumlah santri tidak dapat ditentukan dengan pasti karena masuk dan keluarnya santri dengan berbagai alasan tidak tercatat dengan baik. Bahkan, jumlah yang telah tamat hafalannya pun tidak ditemukan datanya di lapangan. Namun demikian, sejak didirikan hingga tahun 2008, diperkirakan jumlah yang telah keluar kurang lebih 80 orang. Sebagian besar yang telah keluar itu adalah yang telah tamat hafalan Alquran, sebagian lain keluar atas inisiatif mereka sendiri dengan berbagai alasan dan sebagian kecil lainnya dikeluarkan karena pelanggaran. Selain itu, sebagian besar data mengenai keadaan santri dan lembaga yang berada dalam file komputer hilang saat peristiwa kecurian pada tahun 2008 dan tidak ditemukan sampai sekarang.

Berdasarkan keterangan tersebut dapat dipahami bahwa sistim administrasi lembaga ini belum tertata dengan baik. Bukan hanya karena musibah yang menimpanya, tetapi memang Madrasah ini belum memiliki tenaga ahli di bidang administrasi. Hal itu dapat dimaklumi karena Madrasah ini masih dalam tahap perkembangan.

Barulah pada tahun 2009 sistem administrasi mulai ditata dengan baik, sehingga bisa didapatkan data mengenai jumlah santri Madrasah Tahfidz Alquran pada tahun ini. Jumlah santri yang tercatat pada tahun 2009 dapat dilihat dalam table 1.

Tabel 1.

Jumlah Santri-santriwati Madrasah Tahfidz Alquran al-Imam 'Ashim Tahun 2009

\begin{tabular}{|c|l|c|c|c|}
\hline No. & Program & $\begin{array}{c}\text { Jumlah } \\
\text { snntri }\end{array}$ & $\begin{array}{c}\text { Jumlah } \\
\text { snntriwaH }\end{array}$ & $\begin{array}{c}\text { Jumlah } \\
\text { Trtfql }\end{array}$ \\
\hline 1 & $H i$ al-Nazj & 33 orang & 11 orang & 44 orang \\
\hline 2 & Bi al-Gaib & 35 orang & 10 orang & 45 orang \\
\hline \multicolumn{2}{|c|}{ Total } & 68 orang & 21 orang & 89 orang \\
\hline
\end{tabular}

Table 1 menunjukkan bahwa jumlah santri adalah 89 orang yang terbagi dalam dua jenjang program pembelajaran. Peserta didik program bi al-nazhr (baru belajar memperbaiki bacaan Alquran) berjumlah 44 orang, terdiri atas 33 santri dan 11 santriwati. Peserta didik program bi al-gaib (sudah dibolehkan menghafal Alquran) berjumlah 45 orang, terdiri atas 35 santri dan 10 santriwati.

\section{Keadaan Ustadz (Ustadzah) dan Santri}

Madrasah ini memiliki sepuluh orang pembina tetap dengan rincian; seorang pimpinan madrasah merangkap Pembina tahfizh dan qird'ah, seorang bendahara madrasah merangkap pembina tahfizh, enam orang pembina/instruktur tetap tahfizh, seorang pembina ilmu hadis dan seorang pembina tildwah.

Para pembina tersebut terdiri dari delapan orang pembina laki-laki dan dua orang pembina perempuan. Tenaga pengajar laki-laki. khusus mengajar pada Madrasah Tahfidzil Quran Putera. Sementara, tenaga pengajar puteri khusus mengajar pada Madrasah 
Tahfidzil Quran Puteri. Di samping itu, terdapat pula Instruktur tahfizh yang membantu Ustaz H. Syam Amir disebutjuga badal (pengganti). Dalam beberapa kesempatan, santri senior (santri yang sudah menghafal lebih dari 5 juz dan yang sudah khatam) diberikan amanah untuk membina santri yunior (santri yang baru masuk khususnya yang bacaan Alqurannya tidak lancar dan masih perlu di-/a/?sf «/diperbaiki).

Berdasarkan uraian di atas dapat dipahami bahwa bentukpembinaan yang diterapkan tetap mengadopsi bentuk pembinaan yang diterapkan oleh Nabi saw. kepada sahabat di mana Nabi mengangkat beberapa orang sahabat untuk membantu mengajarkan Alquran kepada sahabat yang lain. Ini berarti teori yang telah dikemukakan sebelumnya relevan dengan fakta yang ada.

\section{Keadaan Sarana dan Prasarana Madrasah Tahfidz Alquran al-Imam 'Ashim}

Sarana-prasarana yang menjadi pusat kegiatan Madrasah Tahfidz Alquran Putra adalah Masjid Arraudhah. Masjid ini telah menjadi tempat kegiatan keagamaan khususnya sarana tempat pembelajaran tahfizh Alquran sejak awal berdirinya Madrasah ini.

Asrama selain sebagai tempat istirahat dan juga dijadikan tempat pembelajaran (khususnya bagi santri program bi al-nazhr yang baru masuk) berada di lantai dua dan tiga rumah ustaz H. Syam Amir (Ketua Yayasan dan Pimpinan Madrasah Tahfidz Alquran alImam 'Ashim). Sarana dan prasarana ini sebenarnya belum memadai, tetapi untuk sementara waktu masih dianggap cukup menampung para santri. Namun demikian, sarana dan prasarana tersebut masih perlu pengembangan seiring dengan bertambahnya santri dan berkembangnya kebutuhan madrasah dari tahun ke tahun. Hal inilah yang membuat pengurus madrasah mengupayakan setiap tahunnya untuk menambah sarana dan prasarana dengan jalan mengedarkan proposal pada bulan ramadhan. Pembenahan bangunan dan fasilitas lainnya dilakukan apabila sumbangan (sedekah, infaq) dari para donatur dan dari para orang tua santri telah mencukupi untuk memenuhi satu kebutuhan fasilitas madrasah.

Fasilitas lain yang disediakan adalah Mushaf Alquran cetakan Menara Kudus yang menjadi Mushaf standar untuk hafalan, kitab-kitab qird'dt, kitab-kitab tajwid baik yang lengkap dan berbahasa Arab maupun yang praktis dan berbahasa Indonesia, songkok putih dan alas tidur berupa kasur busa. Konsumsi untuk santri 3 kali sehari. Kaset Murattal dan tilawah oleh para Qurrd' (lokal dan Timur Tengah) yang membantu pembelajaran tersedia dengan beraneka ragam.

Ini berarti bahwa sistem pembelajaran tahfizh Alquran tetap dapat terlaksana dengan baik meskipun dengan fasilitas yang sederhana. Karena yang paling penting menurut Syam Amir adalah niat yang tulus untuk pengabdian.

\section{Pelaksanaan Pembelajaran Tahfizh Alquran}

Pembelajaran tahfizh Alquran di Madrasah Tahfidz Alquran al-Imam 'Ashim diselenggarakan dalam duajenjang program pembelajaran, yaitu:

\section{a. Program bi al-nazjr.}

Program bi al-nazhr adalah program pembelajaran yang diterapkan untuk membina santri yang baru mulai belajar membaca Alquran, santri yang belum mampu membaca Alquran dengan baik dan santri yang sudah pandai membaca Alquran tetapi belum menghafal Juz 30. Bi al-nazhr artinya dengan melihat. Maksudnya adalah santri membaca Alquran dengan melihat mushaf Alquran. Metode yang digunakan adalah metode talaqqi wa al-musydfahah.

Materi yang setiap hari diberikan kepada santri selama mengikuti program bi al-nazhr ini meliputi pelajaran tajwid (ilmu tentang cara melafalkan bacaan Alquran dengan benar) dan fashdhah (latihan kefasihan dalam membaca Alquran) dengan metode jibril. Dinamakan Metode jibril karena terinspirasi dari metode yang dilakukan oleh malaikat Jibril ketika mengajarkan Alquran kepada Nabi saw. Selain itu, santri juga diwajibkan melakukan setoran bacaan $b i$ al-nazhr juz 30 dan Muddrasah. (mengulang-ulang bacaan Alquran) juz 1 hingga juz 3 dengan bacaan murattal (bacaan dalam tempo sedang dan berirama).

\section{b. Program bi al-gaib.}

Program bi al-gaib yaitu program pembelajaran penghafalan Alquran mulai dari juz 1 sampai juz 30 (tamat). Disebut bi al-gaib karena dalam membaca Alquran santri tidak melihat langsung mushaf Alquran khususnya ketika menyetorkan bacaannya dihadapan ustaz. Qird 'ah yang menjadi standar bacaan adalah sama dengan program bi al-nazhr yaitu qird'ah 'Ashim riwayat Hafsh. Program ini dikhususkan bagi santri yang telah menyelesaikan program bi al-nazhr.

Program ini dilaksanakan dengan menggunakan metode talaqqi dan musydfahah (memperdengarkan langsung hafalan kepada guru). Teknis pelaksanakan 
metode ini adalah setiap ustaz mendengarkan bacaan setiap santri dengan cara berhadapan langsung antara ustaz dan santrinya. Santri membaca langsung didepan ustaznya sedang ustaznya mendengarkan dengan seksama bacaan dari santrinya sehingga bila ada kesalahan ustaz dapat mengoreksi dan melakukan tahsin (perbaikan) serta menunjukkan langsung bacaan yang benar.

Dengan demikian, dapat dikatakan bahwa metode ini merupakan metode yang efektif untuk mengarahkan santri membaca dan menghafal Alquran dengan baik dan fasih.

Menurut H. Syam Amir bahwa pembelajaran tahfizh Alquran di Madrasah yang diasuhnya banyak mengadopsi program dan metode pembelajaran yang telah didapatkan di Madrasatul Quran Tebu Ireng Jombang dan mengembangkannya dalam beberapa kegiatan pembelajaran dan materi-materi penunjang lainnya.

Kegiatan sehari-hari santri program bi al-gaib antara lain:

\section{a) Setoran hafalan}

Santri wajib menyetorkan hafalan pada setiap jam wajib setiap hari (kecuali hari Iibur yang dimulai hari kamis sesudah dzuhur sampai jum'at sore) baik ziyddah maupun murdja'ah kepada seorang ustaz. Jam wajib adalah jadwal belajar yang telah ditetapkan dan harus dipatuhi oleh para santri. Ziyddah adalah hafalan baru seorang santri minimal satu halaman setiap hari. Murdja'ah adalah hafalan lama seorang santri yang wajib disetorkan atau dihadapkan setiap harinya kepada seorang ustaz minimal lima halaman atau seperempat juz. Kegiatan ini dilaksanakan 6 (enam) hari dalam seminggu dan tiga kali menghadap perhari. Untuk lebih jelas dapat dilihat dalam Tabel 2.

Tabel 2.

Jam Wajib Menyetorkan Hafalan bagi Santri

\begin{tabular}{|c|c|c|c|l|l|c|}
\hline No. & $\begin{array}{c}\text { Jam } \\
\text { wajib }\end{array}$ & $\begin{array}{c}\text { Mulai } \\
\text { pukul }\end{array}$ & $\begin{array}{c}\text { Berakhir } \\
\text { pukul }\end{array}$ & \multicolumn{1}{|c|}{ Jenis Kegiatan } & Keterangan & Tcmpat \\
\hline 1 & Subuh & $\mathbf{0 6 . 0 0}$ & $\mathbf{0 7 . 0 0}$ & $\begin{array}{l}\text { Ziyadah dan/atau } \\
\text { Muraja 'ah }\end{array}$ & $\begin{array}{l}\text { Setiap hari } \\
\text { kecuali jumat }\end{array}$ & Masjid \\
\hline 2 & Pagi & $\mathbf{0 9 . 0 0}$ & $\mathbf{1 2 . 0 0}$ & $\begin{array}{l}\text { Ziyadah dan/atau } \\
\text { Murafa'ah }\end{array}$ & s.d.a. & s.d.a \\
\hline 3 & Mai am & $\mathbf{2 0 . 3 0}$ & $\mathbf{2 2 . 0 0}$ & $\begin{array}{l}\text { Ziyadah dan/atau } \\
\text { Murafa'ah }\end{array}$ & s.d.a. & s.d.a \\
\hline 4 & $\begin{array}{l}\text { Tamba } \\
\text { han }\end{array}$ & $\mathbf{1 6 . 0 0}$ & $\mathbf{1 7 . 0 0}$ & Fasjfyh tahfiz\} & $\begin{array}{l}\text { Setiap hari } \\
\text { Minggu }\end{array}$ & s.d.a \\
\hline
\end{tabular}

Tabel di atas menunjukkan bahwa santri diwajibkan berada dalam masjid selama $5 \boldsymbol{V z}$ (lima setengah) jam per hari untuk membaca Alquran. Mereka wajib menyetorkan hafalan kepada seorang ustddz baik ziyddah (tambahan hafalan) maupun murdja'ah (hafalan lama yang diulang) dalam 3 (tiga) waktu berbeda, yakni sesudah shalat subuh 1 (satu) jam, pagi sampai menjelang dhuhur 3 (tiga) jam dan sesudah shalat isya $1 \boldsymbol{V i}$ (satu setengah jam). Sebelum dan sesudah menyetorkan hafalan, santri diwajibkan tetap di masjid. Khusus pada hari minggu sore selama 1 (satu) jam mereka dilatih kefasihannya dalam membaca Alquran.

\section{b) Takrir.}

Takrir adalah mengulang-ulang hafalan Alquran. Kegiatan ini merupakan kegiatan yang sangat penting dilakukan oleh para santri yang telah menghafal Alquran baik yang belum menghafal keseluruhan Alquran maupun yang telah menamatkan hafalan Alquran 30 juz. Takrir di Madrasah ini dilakukan oleh santri dengan beberapa cara takrir individu (mengulang sendiri hafalannya), takrir bersama (mengulang secara berkelompok), takrir dalam shalat dan takrir dihadapan ustddz yang diistilahkan dengan murdja 'ah.

\section{c) Fashdhah tahfizh.}

Kegiatan ini bertujuan melatih kefasihan santri tahfizh dalam melafalkan Alquran dengan cara dihafal. Kegiatan ini dilaksanakan sekali dalam sepekan setiap jam wajib tambahan. Ayat-ayat yang menjadi materi fashdhah merupakan ayat-ayat yang sudah dihafal oleh para santri sesuai dengan semesternya.

Adapun santriwati program bi al-gaib, waktu belajar mereka adalah dua hari dalam seminggu. Untuk lebih jelas dapat dilihat dalam Tabel 3.

Tabel 3.

\section{Jam Wajib Menyetorkan Hafalan} bagi Santriwati

\begin{tabular}{|c|c|c|c|l|l|c|}
\hline No & $\begin{array}{c}\text { Jam } \\
\text { wajib }\end{array}$ & $\begin{array}{c}\text { Mulai } \\
\text { pukul }\end{array}$ & $\begin{array}{c}\text { Berakhir } \\
\text { pukul }\end{array}$ & \multicolumn{1}{|c|}{ Jenis Kegiatan } & Keterangan & Tempat \\
\hline 1 & Sore & 16.00 & 17.00 & $\begin{array}{l}\text { Takrir individu } \\
\text { (mengulang sendiri } \\
\text { hafalannva) }\end{array}$ & $\begin{array}{l}\text { Setiap Hari } \\
\text { Sabtu }\end{array}$ & Masjid \\
\hline 2 & Mai am & 20,00 & 22.00 & $\begin{array}{l}\text { Setoran Ziyadah } \\
\text { dan murafa' } \text { 'ah }\end{array}$ & $\begin{array}{l}\text { Setiap Mai am } \\
\text { Minggu }\end{array}$ & s.d.a \\
\hline 3 & Pagi & $\mathbf{0 9 . 0 0}$ & $\mathbf{1 2 . 0 0}$ & $\begin{array}{l}\text { Fas }{ }^{\wedge} \boldsymbol{b}^{\wedge} \text { h. Setoran } \\
\text { Ziyadah dan } \\
\text { murafa 'ah }\end{array}$ & $\begin{array}{l}\text { Setiap Hari } \\
\text { Minggu }\end{array}$ & s.d.a \\
\hline
\end{tabular}

Tabel 3 menunjukkan bahwa santriwati diwajibkan berada dalam masjid selama 6 (enam) jam per pekan untuk membaca Alquran, yaitu pada setiap sabtu dan minggu. Jadwal dan kewajiban santriwati berbeda dengan santri yang tampaknya adalah pelajar. Pada sabtu sore mereka wajib 'melakukan takrir individu selama 1 (satu) jam. Malam minggu mereka wajib menyetorkan hafalan kepada seorang ustddzah baik 
ziyddah (tambahan hafalan) maupun murdja'ah (hafalan lama yang diulang) selama dua jam. Hari minggu, selama 3 (tiga) jam mereka dilatih kefasihannya dalam membaca Alquran dan diwajibkan pula menyetorkan ziyddah maupun murdja 'ah.

Berdasarkan keterangan di atas dapat dipahami bahwa dalam menerapkan sistem pembelajaran tahfizh Alquran maka pengaturan waktu yang baik mesti diterapkan, selain untuk efisiensi dan efektifitas pembelajaran juga untuk melatih kedisiplinan santri dan santriwati dalam menggunakan waktu.

\section{d) Materi tambahan}

Santri Madrasah Tahfidz Alquran juga diberi materi-materi tambahan sebagai penunjang pengetahuan mereka. Materi-materi tambahan itu antara lain:

1) Alquran Mujawwad, Materi ini berisi pelajaran tentang teori ilmu tajwid.

2) Tildwah Alquran, dimaksudkan untuk melatih santri memiliki skill dalam membaca Alquran dengan indah.

3) Dirdsah Islamiyah dan Bahasa Arab, dimaksudkan untuk memberi pemahaman tentang agama Islam seperti pengetahuan tentang tafsir, hadis, fiqhi, tauhid, akhlak, dan bahasa Arab juga diberikan kepada santri.

\section{e) Pelatihan-pelatihan}

Untuk membiasakan santri tampil di depan orang banyak sekaligus melatih mentalnya maka sekali dalam sepekan juga diadakan pelatihan-pelatihan, yaitu; pelatihan Musabaqah Hdifzh Alquran, pelatihan khutbah dan pelatihan shalawat.

Berdasarkan keterangan di atas, dapat diketahui bahwa kegiatan pokok dalam sistem pembelajaran tahfizh Alquran adalah ziyddah dan murdja'ah, namun dapat pula diberikan kegiatan penunjang untuk melatih santri sehingga memiliki wawasan pengetahuan dan skill yang baik sesuai dengan bakat mereka, asalkan ada pengaturan waktu yang baik.

\section{f) Program Khusus Qird'dt sab'ah.}

Dikhususkan bagi para $h d f i z h$ Alquran 30 juz dan para qdri'-qdri 'ah (orang yang terampil melagukan Alquran dengan irama tertentu) yang ingin memperdalam pengetahuannya tentang qird'dt Alquran. Qird'dt sab 'ah adalah tujuh bentuk bacaan Alquran yang disepakati oleh para ulama sebagai bacaanbacaan autentik berasal dari Nabi saw.

\section{Manfaat Pembelajaran Alquran bagi Lingkungan Sekitarnya}

Sebelum Madrasah tersebut didirikan, Tidung Mariolo merupakan daerah yang masyarakatnya masih awam terhadap pemahaman agama meskipun hampir seluruh penduduknya beragama Islam (hanya satu KK yang non muslim). Sebagian di antara masyarakat, moralnya rusak khususnya sebagian kaum pria adalah peminum minuman keras, penjudi, dan pedagang minuman khamr yang dalam bahasa makassar disebut "ballo". Anak-anak bahkan orang tua masih banyak yang buta aksara Alquran. Sebagian kecil yang dapat membaca Alquran pun masih sangat jauh dari kefasihan. Sistem pembelajaran membaca Alquran menggunakan metode tradisional. Metode dimaksud dikenal dengan metode Bagdddiyyah yaitu suatu metode pembelajaran membaca Alquran yang di dalamnya berisi tata cara membaca huruf hila 'iyyah dan juz "Amma (juz 30).

Setelah Yayasan al-1mam 'Ashim berdiri, masyarakat Tidung Mariolo mengalami banyak perubahan, khususnya dalam bidang bacaan Alquran. Kehadiran Madrasah Tahfidz Alquran al-Imam 'Ashim mendapatkan respon positif dari masyarakat tanpa mendapat gangguan dan rintangan. Antusiasme masyarakat memasukkan anak-anaknya untuk belajar bacaan Alquran di TPA Al-lmam Ashim amat tinggi. Bahkan para orang tua pun ada yang ikut belajar membaca Alquran, atas binaan H. Syam Amir dan Imam kelurahan dibantu oleh santri program tahfizh. Kaum pria belajar membaca Alquran dalam kelompok pengajian Majlis Zikir laki-laki. Di samping itu, madrasah ini juga menjalin kerjasama dengan Majlis Taklim al-Raudhah dalam membina anggotanya belajar membaca Alquran. Majlis Taklim al-Raudhah anggotanya seluruhnya adalah perempuan. Selain pembinaan masyarakat dalam mempelajari bacaan Alquran, Madrasah Tahfidz Alquran al-Imam 'Ashim juga senantiasa berpartisipasi membantu masyarakat sekitar pada acara-acara keagamaan seperti khataman Alquran, barzanji, shalawat, Tahlilan dan yasinan.

Beberapa instansi pemerintahan baik pemerintah daerah dalam dan luar provinsi maupun lembaga pendidikan keagamaan dan organisasi kemasyarakatan menjalin kerja sama dengan Madrasah Tahfidz Alquran al-Imam 'Ashim. Instansi dan lembaga dimaksud antara lain: Pemerintah,'masjid-masjid, Lembaga Pengembangan Tilawatil Qur'an (LPTQ) kini berganti nama LPPTQ (Lembaga Pendidikan dan Pengem- 
banganTilawatil Qur'an), Nahdatul Ulama, UMI (Universitas Muslim Indonesia) dalam hal ini Fakultas Agama Jurusan Pendidikan Agama Islam, Jam 'iyyat al-Qurrd' wa al-Huffdzh kota Makassar, dan sebagainya.

Kerjasama yang dilakukan dengan semua pihak tersebut menunjukkan tingkat kepercayaan khalayak dan pemerintah terhadap madrasah ini. Kepercayaan itu diraih tidak dengan jalanmudah, melainkan diperoleh dengan kerja keras dan penuh kesungguhan dalam menjalankan proses pembinaan dan pembelajaran, terutama yang terkait dengan Alquran. Kerja keras dan kesungguhan tersebut akan semakin dibutuhkan di masa-masa yang akan datang demi kemajuan dan kesinambungan perjalanan madrasah tersebut.

\section{PENUTUP}

\section{Kesimpulan}

Berdasarkan uraian-uraian di atas maka dapat disimpulkan bahwa meski dengan sarana dan prasarana yang sederhana, Madrasah Tahfidz Alquran al-Imam Ashim mampu menerapkan dan mengembangkan pembelajaran tahfizh Alquran dengan menggunakan metode talaqqi wa al-musydfahah. Metode tersebut diterapkan dalam dua program yaitu program bi al-nazhr untuk santri dan santriwati yang baru belajar membaca Alquran dan program bi algaib untuk santri dan santriwati yang sedang dalam tahap menghafal Alquran. Madrasah ini berkembang secara bertahap dari tahun ke tahun dan telah menghasilkan sejumlah hafizh Alquran berkualitas. Pembelajaran tahfizh Alquran di Madrasah ini bermanfaat cukup besar dalam mengubah pola pikir dan prilaku masyarakat menjadi lebih agamis dan puny a semangat untuk membaca atau memperbaiki bacaan Alqurannya.

\section{DAFTAR PUSTAKA}

AE, Hasanuddin. 1995. Anatomi Alquran; Perbedaan Qira'at dan Pengaruhnya Terhadap Istinbath Hukum. Cet. I; Jakarta: RajaGrafindo Persada.

Amal, Taufik Adnan. 2001. Rekonstruksi Sejarah Alquran, Edisi I. Cet. I; Yogyakarta: FkBA.

al-Bukhari al-Ju'fi, Abu 'Abdullah Muhammad ibn Isma'il ibn Ibrahim ibn al-Mugirah ibn Bardizabah. 1412 H/1992 M. Shahih Bukhdri, Juz VI. Cet. I; Beirut: Dar al-Kutub al'Ilmiyyah.

Departemen Agama Republik Indonesia, Yayasan Penyelenggara Penerjemah/Pentashih Mushaf Alquran. 2005. Alquran dan Terjemahnya. Bandung: PT. Syaamil Cipta Media.
Dhif, Syauqi. T. th. Kitdb al-Sab 'ah li Ibn al-Mujdhid. Cet.III; Kairo: Dar al-Ma'arif.

Fathoniy, Ahmad. 1996. Kaidah Qira'at Tujuh, Jilid 1. Cet. II; Jakarta: Darul Ulum Press.

Isma'il, Sya'ban Muhammad. 1993. Al-Qird'atu Ahkdmuhd wa Mashddruhd diterjemahkan oleh Said Agil Husin alMunawar, Abdurrahman Umar dan Nashrullah Jamaluddin dengan judul Mengenai Qira 'at Alquran. Cet. I; Semarang: Dina Utama.

al-Jazari, Al-Imam al-Hafizh Abu al-Khair Muhammad ibn Muhammad al-Damasyq? ibn. 1418 H./1998 M. Al-Nasyrfi al-Qird 'at al- 'Asyr, Juz I. Cet. I; Beirut: Dar al-Kutub al'Ilmiyyah.

al-Shabuni, Muhammad 'All. 1405 H./1 985 M. Al-Tibydn fi 'Ulum al-Qur'dn. Cet. I; Beirut: 'Alim al-Kutub.

Salim, Sihr al-Sayyid 'Abd al-'Aziz. 1411 H./1991 M. 'Adwd'u 'aid Mushaf 'Utsmdn ibn 'Affdn wa Rihlatih Syaraqan wa Garaban. Iskandariyah: Mu'assasah Syabab al-Jami'ah.

Sugiyono. 2009. Metode Penelitian Kuantitatif, Kualitatif dan R \& D (Cet. VI; Bandung: Alfabeta.

2007. Memahami Penelitian Kualitatif. Cet. Ill; Bandung: Alfabeta.

al-Qaththan, Manna' Khaltl. T. th. Mabdhitsfi 'Ulum al-Qur'dn. Cet. Ill; t.tp.: Mansyurat al-'Ashr al-Hadits. 